\title{
QUO VADIS, MEDICÍNSKA ETIKA?
}

\section{Libuša Radková1, Ladislav Šoltés ${ }^{2}$, Marta Vaverčákováa ${ }^{3}$ Mária Gažiová ${ }^{4}$}

${ }^{1}$ Trnavská univerzita v Trnavě, Fakulta zdravotníctva a sociálnej práce, katedra misijnej práce a dobrovol'níctva

2 Slovenská zdravotnícka univerzita

${ }^{3}$ Trnavská univerzita, Fakulta zdravotníctva a sociálnej práce, katedra aplikovanej sociálnej práce

${ }^{4}$ Vysoká škola zdravotníctva a sociálnej práce sv. Alžbety, n. o., Bratislava

Porevolučná eufória orientovaná na humanistické, demokratické a etické hodnoty a vyjadrovaná spontánne temer celou spoločnost'ou pomaly vyprcháva. Heslá ako hovorme si pravdu, bud'me tolerantní, pomáhajme si navzájom, bud'me svorní, neobohacujme sa na úkor iných a mnohé iné už dnešnému človeku vel'a nehovoria. Skôr naopak akoby l'udia pochopili, že byt' úspešný predpokladá dnes často charakterové prvky bezohl'adnosti, tvrdosti, podvodu, schopnosti tunelovat', menit' politickú i svetonázorovú príslušnost' a angažovanost' podl'a predpokla-daného osobného prospechu $\mathrm{v}$ oblasti materiálnej, v spoločenskom postavení a $\mathrm{v}$ ko-nečnom dôsledku v mocenskom zisku. Teda všetko, len nie etika, o ktorej sa dnes tak často hovorí.

Tieto nálady prežívajú príslušníci všetkých profesií a generácií okrem tých, ktorí zo svojich zištných aktivít egoisticky t’ažia. Ani povolanie lekára nie je uchránené od týchto moderných tendencií. Naopak nekompetentné a dlhotrvajúce neefektívne reformy zdravotníckej starostlivosti, neprehl'adná privatizácia, včítane zdravotníckych a kúpel’ných zariadení, politická nestabilita a rôzne kauzy, tendenčné kritiky zamerané na prácu lekárov spolu s ich neprimeraným finančným ocenením $\mathrm{v}$ porov-naní s inými profesiami otravujú a znehod-nocujú prácu výkonných zdravotníkov, ktorí sami sú mimo reforiem, sporov medzi rezortom, poist'ovňami, lekárskou komorou ako aj odbormi.

Má ešte verejnost' právo $\mathrm{v}$ tejto celospoločenskej atmosfére očakávat' a vyžado-vat' od lekára vyšší etický štandard než od iných povolaní a profesií? Je etický profil lekára len zrkadlovým obrazom celej spoločnosti? Tieto a podobné otázky rezonujú tak medzi zdravotníkmi, ako aj vo verejnosti. Alebo vzhl'adom na hodnotu zdravia je lekárske povolanie spojené s tak vysokou zodpoved-nost'ou, že sa etické princípy predpokladajú akosi samozrejme i s vysokými požiadavkami na odbornú a etickú úroveň zdravotníkov, a to predovšetkým lekárov?

Tlaky na potreby etiky v medicíne stále stúpajú. Ekonomické, vedecké i spoločenské tlaky na konci 20. a na začiatku 21. storočia nútia už i vlády, medzinárodné organizácie i organizátorov zdravotníckej starostlivosti na celom svete do reformy medicíny a zdravotní-ctva spojenej s rešpektom $\mathrm{k}$ etickým normám a princípom. I úspechy medicíny, ktoré nemajú obdobu v dejinách medicíny, sú dvojsečné. Cenou za tieto úspechy bol nárast chronických ochorení a predíženie života spojené často $\mathrm{s}$ vyššou morbiditou či polymorbiditou starých l'udí, neraz väčšie utrpenie a $\mathrm{v}$ ekonomickej rovine $\mathrm{s}$ vyššími nákladmi. Mnohé vlády bohatých i chudobných štátov preto ponechali medicínu sút'ažit' o obmedzené zdroje s požiadavkami iných rezortov, ako je školstvo, sociálna oblast', ale i boj s nezamestnanost'ou a chudobou, terorizmom, ale i obranou a zbrojením. Všetky štáty sa stretávajú s problémom stále sa zväčšujúcimi nákladmi na zdravotnícku starostlivost' a hl'adaním zdrojov na ich hradenie. Lekár sa často stretáva s požiadavkou znižovat' náklady od rezortu, svojich nadriadených, poist'ovne a pritom reagovat' na stále sa zvyšujúce nároky pacientov a narastajúce ponuky nových efektívnejších technológií a farmaceutických firiem. Otázkou potom bude, čo závisí od neho a čo je v jeho silách a možnostiach pre potreby pacienta zabezpečit' z pohl'adu čiste profesionálneho, ale i etického. Mohli by sme to sumarizovat' i takto z pohladu práv pacienta, ekonomických možností spoločnosti a vlastnej profesie a etiky. $V$ našom príspevku sa zameriame skôr na lekára.

Medicína je často definovaná ako veda a umenie zaoberajúca sa diagnózou, liečbou 
chorôb a udržovaním zdravia. Taká konvenčná definícia nemôže vyjadrit' celú šírku medicíny a jej mnohé dimenzie, ale jasne potvrdzuje spojenie vedy a umenia v jednej profesii lekára. Okrem lekárov ide o d'alšie profesie, ako sú sestry, laboranti, rehabilitační pracovníci ako aj celý rad nezdravotníckych profesií, ktoré rovnako ovplyvňujú úroveň zdravotníckej starostlivosti a vplývajú tak na kvalitu zdravotníckej starostlivosti i spokojnost' pacientov.

Najčastejšia dnešná st'ažnost' našich zdravotníkov je nedostatok financií. Etika je filozofia mravnosti a má čo povedat' nielen do zásadných nových problémov súvisiacich s pokrokom vedy a technológií, ale i do alokácie zdrojov a stanovenia priorít. $\mathrm{V}$ situácii obmedzených zdrojov, ako je tomu v rozvojo-vých krajinách a $\mathrm{v}$ našich podmienkach postkomunistického štátu, má etika svoje nezastupitel'né miesto i v riešení vzt'ahu lekár - pacient, odkial’ pochádza väčšina st'ažností našich pacientov. Parafrázovane kantovských otázok o ciel'och filozofie bude pre medicínu a zdravotnícku starostlivost' podobnou otázkou adresovanou všetkým zdravotníckym pracovní-kom dneška otázka: Čo mám a môžem urobit' ja, lekár na ktoromkol’vek mieste môjho pôsobenia?

Najčastejšou charakteristikou verejnosti je lamentovanie a kritika, ale už menšia snaha osobne niečo urobit', i ked' si pritom môže človek zašpinit' ruky. Avšak to nie je cesta $\mathrm{k}$ riešeniu problémov, ktoré nemôže riešit' len vláda, rezort, vedúci pracovníci, ale každý z nás. Ide o nový postoj, ktorý je založený na spoluzodpovednosti každého zamestnanca za svoj podnik, za svoju inštitúciu a zariadenie, kde žije a pracuje. Teda otázka Quo vadis, medicínska etika, je otázkou, pred ktorou nielen že stojí každý lekár, ale nesie i svoj podiel zodpovednosti za úroveň a kvalitu zdravotníckej starostlivosti. Nikto nepochybuje o tom, že zdravotníctvo potrebuje a bude stále viac potrebovat' finančné zdroje. Avšak nielen to. Môžeme byt' chudobní a predsa môžeme byt' slušní, ústretoví a chovat' sa a pracovat' podl'a profesionálnych a etických noriem.

Pokúsme sa teraz postavit' do pozície nášho pacienta s jeho zdravotnými problémami, pre ktorého stoja tieto na prvom mieste a ktorý očakáva od lekára jeho pomoc $\mathrm{v}$ tom, že bude schopný určit' jeho diagnózu, nasadit' účinnú liečbu a vysvetlit' prognózu. Chce vediet', aké sú príčiny jeho príznakov a ako sa budú vyvíjat'.

$\mathrm{V}$ tomto procese bude budúca spolupráca lekára a pacienta závisiet' od dobrej vzájomnej komunikácie. Pacient citlivo vníma, či ho lekár počúva, či má čas na jeho otázky a či rozptyluje jeho obavy. Často pacienti si všímajú lekára, ako vel’mi je zamestnaný a zápasí s nedostatkom času. Pritom pacienti súčasne očakávajú od lekára dôvernost'. Nie všetci pacienti vyhl'adávajú lekára z čiste zdravotných dôvodov, niektorí sa cítia osamelí a potrebujú, aby ich niekto vypočul a prejavil pozornost' a sympatie. Mnohé závisí od emočného a racionálneho obojstranného spracovania prvého dojmu zo stretnutia lekára s pacientom pri budovaní ich vzájomnej dôvery.

Etickou komponentou práce lekára je aj schopnost' pripustit' si chyby a omyly. Mýlit' sa nemusí znamenat' synonymum zanedbania, nemusí byt' prejavom nevedomosti a neskúsenosti. Niekedy sú to práve úspechy lekára, ktoré ho robia necitlivým k vlastným chybám, a súčasne sú mnohí lekári schopní nachádzat' chyby u iných. Najčastejšie sa chyby robia pri únave lekára a ked' sa musí ponáhl'at'. Mnohé pokroky sa dosiahli vo vede práve objektívnou analýzou chýb a omylov.

Konečný efekt hodnotenia lekára pacientom je založený na kvalitnej komunikácii a vybudovaní vzájomnej dôvery. Pri jej budovaní bude dôležitý okrem komunikačných zručností holistický prístup lekára. Okrem telesnej a duševnej dimenzie zdravia pacienta potrebuje počítat' s dimenziou sociálnou a duchovnou. Práve pribúdajú práce zaobera-júce sa vplyvom religiozity a spirituality na zdravie, priebeh chorôb a prognózou. Opakovane sme poukazovali na pribúdajúce práce o význame spirituality pri riešení stresových situácií vôbec ako aj pri udržovaní zdravia a prekonávaní chorôb (Radková, 2004).

V etickom kontexte je pre lekára nevyhnutné, aby sa vyhol akýmkol'vek prejavom arogancie a dôveru pacienta neznižoval svojou zlou životosprávou, osobným životom a škodlivými návykmi, ako je alkoholizmus a drogy. Je totiž pod drobnohladom svojich pacientov, okolia a verejnosti.

Pod tlakom morálnych konfliktov, ktoré hýbu celou spoločnost'ou, sa tradičný etický systém často spochybňuje a nový nie je, i ked' sa iste očakáva, že bude definovaný. A tak je na mieste otázka, ako bude medicínska etika vyze- 
rat' v budúcich desat'ročiach.

$\mathrm{V}$ tomto procese hl'adania východísk môže priniest' nové podnety morálna filozofia, ak nechceme naše etické uvažovanie ponechat' na intuícii a vnútornom hlase.

Do dialógu s filozofmi však musia vstúpit' lekári a ostatní zdravotníci, ale aj pacienti, teda verejnost'. Podl'a Pellegrina (1993) ide o štyri etapy vývoja medicínskej etiky:

1. dlhé a pomerne kl’udné obdobie posthippokratovské, obohacované behom stáročí najmä krest'anstvom až do 60. rokov minulého storočia;

2. obdobie so vstupom filozofických analýz v 60. rokoch a z nich vyplývajúcich zmien niektorých morálnych teórií doteraz postavených na hippokratovských princí-poch;

3. obdobie spochybňovania definovaných princípov, teda antiprincípov;

4. obdobie krízy, ked' koncepčné konflikty a určitá skepsa voči etike ako filozofii mravnosti spochybňujú univerzálnu norma-tívnu etiku v medicíne.

Môžeme iste polemizovat' o existencii týchto etáp, ale ak sa dokážeme postavit' s otvorenými očami voči realite, tak krízu v etike treba pripustit' a hl'adat' riešenie. A to i tým, že sa nebudeme obávat' nadhadzovat' otázky i vtedy, ked' nemáme ešte jednoznačné odpovede, ale ich hladáme iv tomto príspevku. $\mathrm{V}$ našich podmienkach sú strety etických postojov v hnutiach pro life a pro choice alebo v otázkach o výhradách svedomia lekára a vôbec zdravotníka príkladom takých stretov svetoná-zorových, že nejaký konsenzus je v súčasnosti nedosiahnutel'ný.

\section{LITERATÚRA}

8th European Congres of FEAMC: Medicine today and our image of man. Prague: June 5-9, 1996. Proceeding, 1996. p. 271.

CALLAHAN, D.: The troubled dream of life, New York: Simon and Schuster, 1993. $246 \mathrm{~s}$.

DOLISTA, J., SAPÍK, M.: Studie z bioetiky, 1. vyd., České Budějovice: JU ZSF, 2006.

HALÍK, T.: Sedm úvah o službě nemocným a trpícím, 1. vyd., Brno: Cesta, 1993. $253 \mathrm{~s}$.

Charta pracovníků ve zdravotnictví, Praha: Zvon, 1996. $110 \mathrm{~s}$.

MILLER, R.: Albert Schweitzer, zástance kritického myšlení a úcty k životu, Praha: Vyšehrad, 1981. $308 \mathrm{~s}$.

PACOVSKÝ, V.: O klinické medicíně, Praha: Univerzita Karlova, 1989. $95 \mathrm{~s}$.

PELLEGRINO, E.: Proměna lékařské etiky, Jama, Praha: UK, 1993. Vol.1, no 6, $488 \mathrm{~s}$.

RADKOVÁ, L.: Religiozita a spiritualita $v$ sociálnej práci, 1. vyd., Bratislava: GaK, 2004. 196 s.

ŠOLTÉS, L. et al.: Vybrané kapitoly z medicínskej etiky, 1. vyd., Bratislava: Univerzita Komenského, 1994. 102 s. Karlova, 1989. 95 s.

\section{Radková Libuša et al. lradkova@truni.sk}

